\title{
Genetic polymorphisms in biotransformation enzymes in Crohn's disease: association with microsomal epoxide hydrolase
}

\author{
D J de Jong, E M J van der Logt, A van Schaik, H M J Roelofs, W H M Peters, \\ T H J Naber
}

See end of article for authors' affiliations

\section{Correspondence to:} Dr D J de Jong, Department of Gastroenterology and Hepatology, University Medical Centre Nijmegen $\mathrm{PO}$ Box $9101,6500 \mathrm{HB}$ Nijmegen, the Netherlands;

d.dejong@gastro.azn.nl

Accepted for publication 4 November 2002

\begin{abstract}
Background: Mucosal biotransformation enzymes can modify toxic compounds in the gut. As chemical or oxidative stress may be involved in the aetiology of Crohn's disease, genes encoding for enzymes involved in the prevention of such stress may be candidates for genetic susceptibility to Crohn's disease.

Aim: To assess the association of Crohn's disease with genetic polymorphisms in cytochrome P450 $1 \mathrm{~A} 1$, glutathione S-transferases mu-1, pi-1, and theta-1, and epoxide hydrolase.

Methods: $\chi^{2}$ square analysis was used to compare frequencies of polymorphisms between 151 patients with Crohn's disease and 149 healthy controls.

Results: In patients, a genetic polymorphism in exon 3 of the microsomal epoxide hydrolase gene was distributed significantly different compared with controls $\left(\chi^{2}=23.7 ; \quad p<0.0001\right)$. All other polymorphisms tested were equally distributed between patients and controls.

Conclusions: Microsomal epoxide hydrolase may play a role in the pathophysiology of Crohn's disease. Furthermore, the epoxide hydrolase gene is located on chromosome 1q, close to a region previously linked to Crohn's disease.
\end{abstract}

Abbreviations: Arg, arginine; CYPlA1, cytochrome P450 1Al gene; EPXH, microsomal epoxide hydrolase gene; GSTM1, glutathione S-transferase mu-1; GSTP1, glutathione S- transferase pi-1; GSTT1, glutathione S-transferase theta-1; His, histidine; lle, isoleucine; PCR, polymerase chain reaction; RFLP, restriction fragment length polymorphism; ROS, reactive oxygen species; Tyr, tyrosine; Val, valine. 
were divided into two groups on the basis of median age of onset. Behaviour of disease was divided into fistulising or non-fistulising disease. Furthermore, a distinction was made for bowel resections in the past as a consequence of stricturing or refractory disease.

Healthy Dutch Caucasians matched for age and sex were used as controls. In two of 151 healthy controls, DNA isolation was unsuccessful. The investigations were approved by the local ethics committee on human experimentation.

\section{Genomic DNA isolation}

Blood samples were collected by venepuncture in sterile EDTA tubes (Greiner, Kremsmünster, Austria or Becton Dickinson, San Jose, California, USA). Whole blood was stored at $-80^{\circ} \mathrm{C}$ until use. The method of Miller and colleagues ${ }^{13}$ was used for genomic DNA isolation from blood lymphocytes of patients. In controls, genomic DNA was isolated from whole blood using the Wizard genomic DNA purification kit, according to the manufacturer's instructions (Promega, Madison, Wisconsin, USA).

\section{Polymerase chain reaction-restriction fragment length polymorphism (PCR-RFLP) CYPlAl}

For demonstrating genetic polymorphism in the $3^{\prime}$-flanking region of CYPIAl, a primer set $5^{\prime}$-TAG GAG TCT TGT CTC ATG CCT-3' and 5'-CAG TGA AGA GGT GTA GCC GCT-3' was used so that the presence of the rare $C$ nucleotide resulted in the appearance of an Mspl restriction enzyme site. ${ }^{14}$ According to this method, a single 340 base pair fragment indicates the presence of homozygous wild-type, 340,200, and 140 base pair fragments demonstrate heterozygote alleles, whereas 200 and 140 base pair fragments indicate the presence of homozygous rare alleles. Genetic polymorphism in exon 7 of CYPIAl was detected using the primer set $5^{\prime}$-GAA CTG CCA CTT CAG CTG TCT-3' and 5'-CCA GGA AGA GAA AGA CCT CCC AGC GGG CCA-3'. The presence of the rare A to G mutation resulted in loss of a Ncol restriction enzyme site. ${ }^{15}$ Analysis by gel electrophoresis (3\% Pronagarose D-ILE) revealed 163 and 32 base pair fragments in individuals with two wild- type alleles (isoleucine (Ile)) and a single 195 base pair fragment when the polymorphism (A to G, Ile to valine (Val)) was present in both alleles. Heterozygotes were indicated by the presence of 195, 163, and 32 base pair fragments.

Glutathione S-transferases $M 1, T 1$, and $\mathrm{Pl}$

Genetic polymorphism in GSTMI was determined by PCR according to the method of Brockmöller and colleagues. ${ }^{16} \mathrm{PCR}$ primers (G2/G3: 5'-CTG GAT TGT AGC AGA TCA TGC-3'/5' CTC CTG ATT ATG ACA GAA GCC-3') were designed according to the known GSTMI cDNA sequence. The PCR amplificates were subjected to electrophoresis on $1 \%$ agarose gels (Agarose MS) and analysed for the presence of a 650 base pair product, which was indicative of a functional GSTMI gene. Lack of an amplification product is consistent with the null genotype. The procedure to detect the polymorphism in GSTT1 is very similar to that of GSTMI and has been described by Pemble and colleagues. ${ }^{17}$ The primers used were: $5^{\prime}$-TTC CTT ACT GGT CCT CAC ATC TC-3' and 5'-TCA CCG GAT CAT GGC CAG CA-3'. Visualisation of a 480 base pair fragment indicates the presence of a functional GSTTI gene. Samples showing negative results for GSTTI or GSTMI were always repeated in another series to exclude misinterpretation of results, and results in the second analysis were found to be $100 \%$ identical. To detect genetic polymorphisms at the GSTPI locus, a PCR assay was used based on the method by Harries and colleagues. ${ }^{18}$ The following primers were used: P105F (5'-ACC CCA GGG CTC TAT GGG AA-3') and P105R (5'-TGA GGG CAC AAG AAG CCC CT-3'). This method revealed a single 176 base pair fragment (homozygous wild-type), 176, 91, and 85 base
Table 1 Characteristics of patients with Crohn's disease and controls

\begin{tabular}{lll}
\hline & $\begin{array}{l}\text { Patients } \\
(\mathrm{n}=151)\end{array}$ & $\begin{array}{l}\text { Controls } \\
(\mathrm{n}=149)\end{array}$ \\
\hline Sex (M/F) & $54 / 97$ & $54 / 95$ \\
Age (y) & $38(1)$ & $38(1)$ \\
Age of onset of Crohn's disease (y) & $25(1)$ & \\
Location of disease* & & \\
$\quad$ leum & $38(26 \%)$ & \\
$\quad$ Colon & $31(21 \%)$ & \\
$\quad$ lleocolonic & $79(53 \%)$ & \\
Fistulising disease* & $79(53 \%)$ & \\
History of bowel resections* $^{*}$ & $89(60 \%)$ & \\
\hline
\end{tabular}

Data are expressed as mean (SEM) or number

* In three patients these detailed data were missing in the medical records.

pair fragments (heterozygote), and 91 and 85 base pair fragments (homozygous polymorphic).

\section{Microsomal epoxide hydrolase}

Separate PCR assays were used to detect two distinct polymorphisms in the EPXH gene. In exon 3, a $\mathrm{T}$ to $\mathrm{C}$ polymorphism, changing tyrosine (Tyr) 113 to histidine (His), was tested. The assay used the primer pair 5'-CTT GAG CTC TGT CCT TCC CAT CCC- $3^{\prime}$ and $5^{\prime}$-AAT CTT AGT CTT GAA GTG ACG GT-3'. The reverse primer contains a mismatched $\mathrm{C}$ residue that creates a Tht 111 I restriction site. ${ }^{19}$ The Tyr 113 allele was identified by an undigested single DNA band of 231 base pairs whereas the His 113 allele gave two bands of 209 and 22 base pairs. In exon 4, an A to G polymorphism was tested, changing His 139 to arginine (Arg). The primer pair 5'-GGG GTA CCA GAG CCT GAC CGT and 5'-AAC ACC GGG CCC ACC CTT GGC was used to assay this polymorphism. ${ }^{20}$ His 139 alleles were identified by two DNA bands ( 295 and $62 \mathrm{bp}$ ) whereas Arg 139 alleles produced three bands (174, 121, and $62 \mathrm{bp}$ ) after digestion. Heterozygous individuals displayed all four DNA fragments $(295,174,121$, and 62 bp).

\section{Statistical analysis}

Data are expressed as mean (SEM). The statistical significance of differences in the distribution of polymorphisms between groups was tested using $\chi^{2}$ analysis with Yates' correction. Where appropriate, $2 \times 2,2 \times 3$, or $3 \times 3$ contingency tables were used. Based on the observed allele frequencies, odds ratios with $95 \%$ confidence intervals (95\% CI) were calculated. In order to detect differences of at least $20 \%$ between groups with $80 \%$ power, and an anticipated genotype frequency of $50 \%$ for the genotype of interest in the control group, 150 subjects per group were needed. In total, seven different genetic polymorphisms were analysed. To take into account the number of comparisons, a two tailed $\mathrm{p}$ value of less than 0.007 instead of 0.05 was considered to represent statistical significance $(0.05$ divided by 7).

\section{RESULTS}

\section{Patients and controls}

Clinical characteristics of patients and controls are given in table 1. Mean age of patients was 38 (1) years at the time of venepuncture, and age at onset of Crohn's disease was 25 (1) years. Crohn's disease was confined to the ileum in 38 patients $(26 \%)$ and to the colon in 31 patients $(21 \%)$. Both ileal and colonic disease was present in 79 patients $(53 \%)$. In three patients no detailed data on disease location and/or disease behaviour were available in the medical records. Bowel resections had been performed in 89 patients $(60 \%)$ and fistulae were present in 79 patients (53\%). Mean age of the healthy controls was 38 ( 1 ) years. 
Table 2 Frequencies of genetic polymorphisms in genes encoding for biotransformation enzymes in patients with Crohn's disease and controls

\begin{tabular}{|c|c|c|c|c|}
\hline Genetic polymorphism & No of patients (\%) & No of controls (\%) & $\begin{array}{l}\text { Odds } \\
\text { ratio }\end{array}$ & $95 \% \mathrm{Cl}$ \\
\hline \multicolumn{5}{|c|}{ CYPIAl (3'-flanking region) } \\
\hline $\mathrm{T} / \mathrm{T}$ & $130(86)$ & $125(84)$ & \multirow{3}{*}{0.87} & \multirow{3}{*}{$0.30-2.49$} \\
\hline $\mathrm{T} / \mathrm{C}$ & $20(13)$ & $24(16)$ & & \\
\hline $\mathrm{C} / \mathrm{C}$ & $1(1)$ & $0(0)$ & & \\
\hline \multicolumn{5}{|l|}{ CYPIAl (exon7) } \\
\hline lle/Ile & $129(86)$ & $122(82)$ & \multirow{3}{*}{0.70} & \multirow{3}{*}{$0.27-1.83$} \\
\hline $\mathrm{lle} / \mathrm{Val}$ & $20(13)$ & $22(15)$ & & \\
\hline $\mathrm{Val} / \mathrm{Val}$ & $2(1)$ & $5(3)$ & & \\
\hline \multicolumn{5}{|l|}{ GSTMI } \\
\hline Wild-type & $69(46)$ & $75(50)$ & \multirow[t]{2}{*}{1.17} & \multirow[t]{2}{*}{$0.67-2.05$} \\
\hline Deletion & $82(54)$ & $74(50)$ & & \\
\hline \multicolumn{5}{|l|}{ GSTTI } \\
\hline Wild-type & $128(85)$ & $119(80)$ & \multirow[t]{2}{*}{0.71} & \multirow[t]{2}{*}{$0.34-1.47$} \\
\hline Deletion & 23 (15) & $30(20)$ & & \\
\hline \multicolumn{5}{|l|}{ GSTP1 } \\
\hline $\mathrm{lle} / \mathrm{lle}$ & 75 (49) & $87(58)$ & \multirow{3}{*}{1.37} & \multirow{3}{*}{$0.72-2.58$} \\
\hline $\mathrm{lle} / \mathrm{Val}$ & $63(42)$ & $55(37)$ & & \\
\hline $\mathrm{Val} / \mathrm{Val}$ & $13(9)$ & $7(5)$ & & \\
\hline \multicolumn{5}{|l|}{ EPXH (exon 3) } \\
\hline $\mathrm{His} / \mathrm{His}$ & $20(13)$ & $59(40)$ & \multirow{3}{*}{$2.92 *$} & \multirow{3}{*}{$1.64-5.20$} \\
\hline Tyr/His & $60(40)$ & $58(39)$ & & \\
\hline Tyr/Tyr & 71 (47) & $32(21)$ & & \\
\hline \multicolumn{5}{|l|}{ EPXH (exon 4) } \\
\hline $\mathrm{His} / \mathrm{His}$ & $90(60)$ & $98(66)$ & \multirow{3}{*}{1.36} & \multirow{3}{*}{$0.68-2.72$} \\
\hline $\mathrm{His} / \mathrm{Arg}$ & $53(35)$ & 48 (32) & & \\
\hline Arg/Arg & $8(5)$ & $3(2)$ & & \\
\hline \multicolumn{5}{|c|}{$\begin{array}{l}\text { CYPIA 1, cytochrome P450 1A1; GSTM1, glutathione S-transferase mu-1; GSTT1, glutathione S- transferase } \\
\text { theta- } 1 \text {; GSTP1, glutathione S-transferase pi-1; EPXH, microsomal epoxide hydrolase; lle, isoleucine; Val, } \\
\text { valine; Tyr, tyrosine; His, histidine; Arg, arginine; } 95 \% \mathrm{Cl}, 95 \% \text { confidence interval. } \\
\text { * } 2 \times 3 \text { table, } \chi^{2}=23.7 ; p<0.0001 \text {. }\end{array}$} \\
\hline
\end{tabular}

Table 3 Freqencies of genetic polymorphisms in the EPXH gene in subgroups of patients with Crohn's disease, divided by disease location and disease behaviour

\begin{tabular}{|c|c|c|c|c|c|c|}
\hline & \multicolumn{3}{|c|}{ EPXH exon 3} & \multicolumn{3}{|c|}{ EPXH exon 4} \\
\hline & $\mathrm{Tyr} / \mathrm{Tyr}$ & Tyr/His & His/His & $\mathrm{His} / \mathrm{His}$ & $\mathrm{His} / \mathrm{Arg}$ & Arg/Arg \\
\hline \multicolumn{7}{|c|}{ Disease location } \\
\hline Ileum & 18 (50) & $13(36)$ & $5(14)$ & $22(61)$ & 12 (33) & $2(6)$ \\
\hline Colon & 15 (49) & $10(32)$ & 6 (19) & 17 (55) & 12 (39) & $2(6)$ \\
\hline Ileocolonic & 33 (43) & 35 (45) & 9 (12) & 45 (58) & $28(36)$ & $4(5)$ \\
\hline \multicolumn{7}{|c|}{ Age of onset (y) } \\
\hline$\leqslant 23$ & 36 (47) & $32(41)$ & $9(12)$ & 41 (53) & $32(42)$ & $9(5)$ \\
\hline$>23$ & 30 (45) & 26 (39) & $11(16)$ & 42 (63) & 21 (31) & $4(6)$ \\
\hline \multicolumn{7}{|c|}{ Fistulae present } \\
\hline Yes & $36(46)$ & $33(42)$ & $9(12)$ & $40(51)$ & $34(44)$ & $4(5)$ \\
\hline No & 30 (45) & 25 (38) & 11 (17) & 44 (67) & 18 (27) & $4(6)$ \\
\hline \multicolumn{7}{|c|}{ Bowel resection } \\
\hline Yes & 42 (49) & 31 (37) & $12(14)$ & $46(54)$ & $36(42)$ & $3(4)$ \\
\hline No & $24(41)$ & $27(46)$ & $8(13)$ & $38(64)$ & $16(27)$ & $5(9)$ \\
\hline
\end{tabular}

Results are given as number of patients $(\%)$.

EPXH, epoxide hydrolase gene; Tyr, tyrosine; His, histidine; Arg, arginine.

The statistical significance of differences for polymorphisms between different groups were analysed by $\chi^{2}$ analysis in $2 \times 3$ or $3 \times 3$ contingency tables. No significant differences were observed.

\section{Genetic polymorphisms}

The distribution of polymorphic variants in CYPIAl, GSTM1, GSTTI, GSTP1, and EPXH genes in patients with Crohn's disease and healthy controls is summarised in table 2 . In exon 3 of the epoxide hydrolase gene, we found a statistically significant higher rate of the Tyr 113/Tyr 113 genotype among patients with Crohn's disease $(47 \%)$ compared with controls $\left(21 \% ; \chi^{2}=23.7, \mathrm{p}<0.0001\right)$. In the patient group, the Tyr 113 allele in exon 3 was more common than in controls, with allele frequencies of 0.67 versus 0.41 , respectively. The corresponding odds ratio for the Tyr 113 allele was 2.9 (95\% CI 1.64-5.20). The genetic polymorphism in exon 4 of the EPXH gene was equally distributed among patients with Crohn's disease and healthy controls, with the rare Arg 139/Arg 139 genotype present in $2 \%$ of controls and $5 \%$ of patients with Crohn's disease. The distribution of genetic polymorphisms in exons 3 and 4 of the EPXH gene in Crohn's disease was not different for subgroups of patients with regard to location of disease, age of onset, presence of fistulae, or a history of bowel resections (table 3).

The rare alleles in the 3'-flanking region and exon 7 of CYPIAl were equally distributed among patients and controls. Furthermore, GSTMI and GSTT1 null genotypes were found in $50 \%$ and $20 \%$ of controls, respectively, and these frequencies were not statistically different from those in the patient population ( $54 \%$ and $15 \%$, respectively). Also, the combination of both GSTM1 null and GSTT1 null genotypes was found equally as often in patients and controls ( $7 \%$ and $13 \%$, respectively; 
$\mathrm{p}=0.6$ ). The Ile to Val substitution in the GSTPI gene was found equally as often in patients and controls.

\section{DISCUSSION}

A imbalance between toxic compounds and detoxifying substances on the luminal side of the gut may play a role in the aetiology of Crohn's disease. Biotransformation enzymes play a pivotal role in a variety of detoxification processes. In this case control study, we found a highly significant difference in allele frequency of the Tyr 13 variant in exon 3 of the EPXH gene between patients with Crohn's disease (0.67) and controls (0.41), resulting in an odds ratio of 2.9 for the Tyr 113 allele. An increased frequency of Tyr 113 in exon 3 in patients may indicate a role for epoxide hydrolase in the genetic susceptibility to Crohn's disease. In vitro, substitution of Tyr for His has been shown to increase EPXH activity by approximately $40 \% .^{20}$ Previously, the presence of epoxide hydrolase activity was demonstrated in the normal human gastrointestinal mucosa. ${ }^{2122}$ An increase in enzyme activity may result in either enhanced activation of endogenous or exogenous substrates to more reactive diol- epoxide derivates or may lead to a more efficient deactivation. In patients with Crohn's disease, altered formation of highly reactive metabolites in the gastrointestinal mucosa due to variations in the EPXH gene may contribute to chronic inflammation and injury to the intestinal wall. An association of variations in the EPXH gene with a variety of malignancies (ovarian, larynx, lung, hepatocellular cancer) and with preeclampsia has been published. ${ }^{193-26}$ An association of this variation in the EPXH gene and Crohn's disease has not been reported previously.

In exon 3 of the EPXH gene, remarkable variation in polymorphic rates has been reported for different ethnic and geographic populations, with frequencies for the Tyr 113 allele in 58-94\% of controls. ${ }^{19} 20242527-29$ All patients and controls in the present study were Caucasian, originating from the Netherlands, a small geographic region. Furthermore, no differences were found for the other genetic polymorphisms determined in the control group in this study compared with other Caucasian control groups. Therefore, bias due to differences in genetic background between patients and controls is unlikely.

Interestingly, the EPXH gene is located on the distal portion of chromosome $1 \mathrm{q},{ }^{30}{ }^{31}$ close to a region linked to inflammatory bowel disease in a report by Hampe and colleagues. ${ }^{32}$

Genetic polymorphisms in the 3 '-flanking region and in exon 7 of CYPIAl, both leading to a more active enzyme, ${ }^{33}$ were found equally often in patients with Crohn's disease and controls. Therefore, we could not demonstrate an association between CYPIAl genotype and the development of Crohn's disease. According to literature databases, no other studies have been performed concerning genetic polymorphisms in CYPIAl in Crohn's disease.

GSTs are involved in the detoxification of a wide variety of toxic compounds, and four main subclasses have been identified in humans. ${ }^{11}$ Previous studies in Crohn's disease demonstrated no differences in the GSTMI gene between patients and controls. ${ }^{34}{ }^{35}$ Duncan et al determined the GSTM1 genotype, while Hertervig et al investigated the GSTMI phenotype. Both studies showed that approximately $60 \%$ of patients lack a functional GSTMl gene or do not express the GSTMI enzyme. In accordance with these studies, no difference was demonstrated between patients and controls. In our population, a deletion in the GSTMI gene was present in $54 \%$ of patients and $50 \%$ of controls. These results indicate that absence of the GSTMI gene does not play an important role in the pathophysiology of Crohn's disease.

In agreement with Duncan and colleagues, ${ }^{34}$ our GSTTI null frequencies did not differ significantly between patients with Crohn's disease (15\%) and controls (20\%), which indicates that lack of this enzyme is not crucial for the development of
Crohn's disease. The frequencies of the null genotype in controls was comparable with that reported in other studies. ${ }^{10} 1736-39$

In the present study, an Ile to Val substitution at codon 105 of the GSTPI gene (GSTPIb variant), resulting in reduced enzyme activity, was demonstrated equally often in patients with Crohn's disease and controls. According to literature databases, no other studies have been performed which have investigated this genetic polymorphism in relation to Crohn's disease. Control populations in previous reports demonstrated very similar frequencies of wild-type, heterozygous, and homozygous genotypes compared with controls in our study. ${ }^{18364041}$ The results in the present study indicate that genetic polymorphisms in GST enzymes do not play an important role in the development of Crohn's disease.

In conclusion, we found no evidence for a possible genetic predisposition to Crohn's disease due to genetic polymorphisms in the CYPIAI, GSTMI, GSTTI, and GSTPI genes. We demonstrated a clear difference in the distribution of variants in the EPXH gene that may lead to an increase in EPXH enzyme activity in patients with Crohn's disease compared with healthy controls. Furthermore, the EPXH gene is located in a region previously linked to Crohn's disease in a genome wide mapping strategy. Although our results strongly indicate a role for the EPXH gene in the genetic susceptibility to Crohn's disease, confirmation of data in an independent cohort of patients and controls would greatly strengthen our conclusion.

\section{Authors' affiliations}

D J de Jong, E M J van der Logt, A van Schaik, H M J Roelofs, W H M Peters, T H J Naber, Department of Gastroenterology and Hepatology, University Medical Centre Nijmegen, the Netherlands

\section{REFERENCES}

1 Hugot JP, Chamaillard M, Zouali $\mathrm{H}$, et al. Association of NOD2 leucine-rich repeat variants with susceptibility to Crohn's disease. Nature 2001;411:599-603.

2 Hampe J, Cuthbert A, Croucher PJ, et al. Association between insertion mutation in NOD2 gene and Crohn's disease in German and British populations. Lancet 2001;357:1925-8.

3 Ogura Y, Bonen DK, Inohara N, et al. A frameshift mutation in NOD2 associated with susceptibility to Crohn's disease. Nature 2001;411:603-6.

4 Cuthbert AP, Fisher SA, Mirza MM, et al. The contribution of NOD2 gene mutations to the risk and site of disease in inflammatory bowel gene mutations to the risk and site of disease in
disease. Gastroenterology 2002;122:867-74.

5 Lesage S, Zouali H, Cezard JP, et al. CARD15/NOD2 mutational analysis and genotype-phenotype correlation in 612 patients with inflammatory bowel disease. Am J Hum Genet 2002;70:845-57.

6 Lih-Brody L, Powell SR, Collier KP, et al. Increased oxidative stress and decreased antioxidant defenses in mucosa of inflammatory bowel disease. Dig Dis Sci 1996;41:2078-86.

7 Sido B, Hack V, Hochlehnert A, et al. Impairment of intestinal glutathione synthesis in patients with inflammatory bowel disease. Gut 1998;42:485-92.

8 Betts WH, Whitehouse MW, Cleland LG, et al. In vitro antioxidant properties of potential biotransformation products of salicylate, sulphasalazine and amidopyrine. J Free Radic Biol Med 1985;1:273-80.

9 Roediger WE, Babidge W. Human colonocyte detoxification. Gut 1997;41:731-4.

10 Wormhoudt LW, Commandeur JN, Vermeulen NP. Genetic polymorphisms of human $\mathrm{N}$-acetyltransferase, cyłochrome P450, glutathione-S-transferase, and epoxide hydrolase enzymes: relevance to genobiotic metabolism and toxicity. Crit Rev Toxicol 1999;29:59-124.

11 Hayes JD, Pulford DJ. The glutathione S-transferase supergene family: regulation of GST and the contribution of the isoenzymes to cancer chemoprotection and drug resistance. Crit Rev Biochem Mol Biol 1995; 30:445-600.

12 Seidegard J, Ekstrom G. The role of human glutathione transferases and epoxide hydrolases in the metabolism of xenobiotics. Environ Health Perspect 1997; 105(suppl 4):791-9.

13 Miller SA, Dykes DD, Polesky HF. A simple salting out procedure for extracting DNA from human nucleated cells. Nucleic Acids Res $1988 ; 16: 1215$

14 Sivaraman L, Leatham MP, Yee J, et al. CYPIAl genetic polymorphisms and in situ colorectal cancer. Cancer Res 1994:54:3692-5.

15 Shields PG, Bowman ED, Harrington AM, et al. Polycyclic aromatic hydrocarbon- DNA adducts in human lung and cancer susceptibility genes. Cancer Res 1993;53:3486-92. 
16 Brockmöller J, Kerb R, Drakoulis N, et al. Genotype and phenotype of glutathione $\mathrm{S}$ - transferase class mu isoenzymes mu and psi in lung cancer patients and controls. Cancer Res 1993:53:1004-11.

17 Pemble S, Schroeder KR, Spencer SR, et al. Human glutathione S-transferase theta (GSTT1): cDNA cloning and the characterization of a S-transferase theta (GST1): CDNA cloning and the char
genetic polymorphism. Biochem J 1994;300:271-6.

18 Harries LW, Stubbins M, Forman D, et al. Identification of genetic polymorphisms at the glutathione $\mathrm{S}$-transferase $\mathrm{Pi}$ locus and association with susceptibility to bladder, testicular and prostate cancer. Carcinogenesis 1997;18:641-4.

19 Lancaster JM, Brownlee HA, Bell DA, et al. Microsomal epoxide hydrolase polymorphism as a risk factor for ovarian cancer. Mol Carcinog 1996:17:160-2

20 Hassett C, Aicher L, Sidhu JS, et al. Human microsomal epoxide hydrolase: genetic polymorphism and functional expression in vitro of hydrolase: genetic polymorphism and functional expre

21 Stahlberg MR, Hietanen E, Maki M. Mucosal biotransformation rates in the small intestine of children. Gut 1988;29:1058-63.

22 Pacifici GM, Franchi M, Bencini C, et al. Tissue distribution of drug-metabolizing enzymes in humans. Xenobiotica 1988;18:849-56

23 Jourenkova-Mironova N, Mitrunen K, Bouchardy C, et al. High-activity microsomal epoxide hydrolase genotypes and the risk of oral, pharynx, and larynx cancers. Cancer Res 2000;60:534-6.

24 Benhamou S, Reinikainen M, Bouchardy C et al. Association between lung cancer and microsomal epoxide hydrolase genotypes. Cancer Res lang cancer and micro

25 McGlynn KA, Rosvold EA, Lustbader ED, et al. Susceptibility to hepatocellular carcinoma is associated with genetic variation in the enzymatic detoxification of aflatoxin B1. Proc Natl Acad Sci U S A $1995 ; 92: 2384-7$

26 Zusterzeel PL, Peters WH, Visser W, et al. A polymorphism in the gene for microsomal epoxide hydrolase is associated with pre-eclampsia. J Med Genet 2001;38:234-7.

27 Wang X, Wang M, Niu T, et al. Microsomal epoxide hydrolase polymorphism and risk of spontaneous abortion. Epidemiology 1998:9.540-4

28 Smith CA, Harrison DJ. Association between polymorphism in gene for microsomal epoxide hydrolase and susceptibility to emphysema. Lancet 1997;350:630-3

29 Salama SA, Sierra-Torres $\mathrm{CH}$, Oh HY, et al. A multiplex-PCR/RFLP procedure for simultaneous CYP2E 1, mEH and GSTM1 genotyping. Cancer Lett 1999:143:51-6.
30 Falany CN, McQuiddy P, Kasper CB. Structure and organization of the microsomal xenobiotic epoxide hydrolase gene. J Biol Chem 1987;262:5924-30.

31 Skoda RC, Demierre A, McBride OW, et al. Human microsomal xenobiotic epoxide hydrolase. Complementary DNA sequence, complementary DNA-directed expression in COS-1 cells, and chromosomal localization. J Biol Chem 1988;263:1549-54.

32 Hampe J, Schreiber S, Shaw SH, et al. A genomewide analysis provides evidence for novel linkages in inflammatory bowel disease in a large European cohort. Am J Hum Genet 1999;64:808-16.

33 Cosma G, Crofts F, Taioli E, et al. Relationship between genotype and function of the human CYPIAl gene. J Toxicol Environ Health 1993;40:309-16.

34 Duncan H, Swan C, Green J, et al. Susceptibility to ulcerative colitis and Crohn's disease: interactions between glutathione S-transferase GSTM 1 and GSTT1 genotypes. Clin Chim Acta 1995;240:53-61.

35 Hertervig E, Nilsson A, Seidegard J. The expression of glutathione transferase $\mathrm{mu}$ in patients with inflammatory bowel disease. Scand J Gastroenterol 1994:29:729-35.

36 van Lieshout EM, Roelofs HM, Dekker S, et al. Polymorphic expression of the glutathione S-transferase P1 gene and its susceptibility to Barrett's esophagus and esophageal carcinoma. Cancer Res 1999;59:586-9.

37 Chenevix-Trench G, Young J, Coggan M, et al. Glutathione S-transferase $M 1$ and $T 1$ polymorphisms: susceptibility to colon cancer and age of onset. Carcinogenesis 1995;16:1655-7.

38 Nelson HH, Wiencke JK, Christiani DC, et al. Ethnic differences in the prevalence of the homozygous deleted genotype of glutathione S-transferase theta. Carcinogenesis 1995;16:1243-5.

39 Kempkes M, Wiebel FA, Golka K, et al. Comparative genotyping and phenotyping of glutathione S-transferase GSTT1. Arch Toxicol 1996;70:306-9.

40 Watson MA, Stewart RK, Smith GB, et al. Human glutathione S-transferase $\mathrm{Pl}$ polymorphisms: relationship to lung tissue enzyme activity and population frequency distribution. Carcinogenesis 1998; 19:275-80

41 Ryberg D, Skaug V, Hewer A, et al. Genotypes of glutathione transferase $\mathrm{Ml}$ and $\mathrm{Pl}$ and their significance for lung DNA adduct levels and cancer risk. Carcinogenesis 1997;18:1285-9. 